\title{
Development and Validation of the Simple and Sensitive Spectrophotometric Method of Amoxicillin Determination in Tablets using Sulphanilamides
}

\author{
Oksana Kostiv, ${ }^{\star}$ Olha Korkuna and Petro Rydchuk \\ Ivan Franko National University of Lviv, Kyryla \&Mefodiya Str., 6, 79005 Lviv, Ukraine \\ *Corresponding author: E-mail: oksanakostiv73@gmail.com
}

Received: 05-15-2019

\begin{abstract}
A rapid, simple and sensitive spectrophotometric method for the determination of amoxicillin (AM) is described. The method is based on the previous sulphanilamide (SA) and sulphathiazole (STZ) diazotization in the medium of $0.6-0.7 \mathrm{M}$ hydrochloric acid and their subsequent interaction with amoxicillin at $\mathrm{pH}=10.5$ with formation of yellow-colored azo compouds. Effective molar absorptivities at the absorbance maxima at $445 \mathrm{~nm}$ (SA) and $448 \mathrm{~nm}$ (STZ) for azo compounds were $(1.74 \pm 0.06) \cdot 10^{4} \mathrm{~L} \times \mathrm{mol}^{-1} \times \mathrm{cm}^{-1}$ and $(1.97 \pm 0.05) \cdot 10^{4} \mathrm{~L} \times \mathrm{mol}^{-1} \times \mathrm{cm}^{-1}$, respectively. Stoichiometric ratios of the components of azo compounds were determined using continuous variations method. Based on the optimum reaction conditions, new methods were developed. These methods allow to determine the amoxicillin in concentration range 1.3-32.9 mg $\times \mathrm{mL}^{-1}$ with sulphanilamide and $0.7-27.4 \mathrm{mg} \times \mathrm{mL}^{-1}$ with sulphathiazole. The methods were successfully validated for amoxicillin determination in tablets "Amoxil".
\end{abstract}

Keywords: Amoxicillin; sulphanilamide; sulphathiazole; spectrophotometry; diazotization; azo-coupling.

\section{Introduction}

Significant development of medicine, chemistry, and biology result in the increased use of biologically active substances, in particular, antibiotics, which occupy an important place in contemporary medical and veterinary practices. The monitoring of their content to evaluate the quality of finished drugs products and detecting the coun- terfeits is a very important task. Since antibiotics often cause side-effects and allergic reactions, it is advisable to control their content in biological fluids, as well as in foods (milk, chicken tissues) because of their extensive use in livestock production. It should be noted that the unjustified entry of antibiotics into the body leads to the emergence of microorganisms resistant to the treatment of bacterial infections. Therefore, it is important to control the

Table 1. Molecular structure and characteristics of amoxicillin ${ }^{4}$

\begin{tabular}{ll}
\hline Structural formula & Characteristic \\
\hline $\begin{array}{l}\text { (2S,5R,6R)-6-\{[(2R)-2-amino-2-(4-hydroxy-phenyl)- } \\
\text { acetyl]amino\}-3,3-dimethyl-7-oxo-4-thia-1-azabicyclo[3.2.0] } \\
\text { heptane-24-carboxylic acid }\end{array}$ & Appearance: white or almost white, crystalline powder. \\
& $\begin{array}{l}\text { Solubility: slightly soluble in water, very slightly soluble in 96\% } \\
\text { ethanol, practically insoluble in fatty oils. It dissolves in dilute acids } \\
\text { and dilute solutions of alkali hydroxides. }\end{array}$ \\
\end{tabular}


presence of antibacterial substances in the wastewater of the pharmaceutical companies for environmental considerations.

Amoxicillin (AM) is a $\beta$-lactam antibiotic belonging to the group of penicillins active against both Gram-positive and Gram-negative bacteria. It is one of the most widely used semi-synthetic penicillins in the treatment of acute bacterial sinusitis and community-acquired pneumonia. ${ }^{1,2}$ The chemical structure of amoxicillin consists of the $d$-4-hydroxyphenylglycine side chain attached to 6-aminopenicillanic acid (6-APA) moiety (Table 1). Amoxicillin, like many other antibiotics, is liable to splitting by $\beta$-lactamase, which is produced by certain bacteria. Therefore, it is often used in combination with clavulanic acid, which is an inhibitor of these enzymes. ${ }^{3}$

When choosing the analytical procedure for antibiotics assay, the nature of the samples in which they are determined is a priority. For the determination of AM in biological fluids ${ }^{6,9,13,15,18}$ (blood plasma, intestinal fluid, urine), multicomponent drugs, ${ }^{5,6,9-11}$ and food products, $3,12,16$ (milk, honey, chicken meat), highly efficient liquid chromatography as well as liquid chromatography coupled with tandem mass spectrometry are used. ${ }^{5-12}$ These techniques are expensive, time-consuming and require the use of organic solvent. Furthermore, spectrophotometry, different types of voltammetry, ${ }^{13-18}$ and titrimetry ${ }^{2}$ as well are used for quantification of AM content in medicines and industrial wastewater. The liquid chromatography is the official pharmacopoeia method ${ }^{1,19}$ of AM determnation in drug substances, capsules, tablets, boluses, oral and injectable suspension. The microbial assay is used for AM determination in intramammary infusion and the iodometry is used for AM assay in oral suspension in soybean oil.

The advantages of spectrophotometry are rapidity and simplicity, low cost of the analysis, and environmental safety. A number of analytical techniques for the AM spectrophotometric determination based on AM own absorbance in the UV spectrum range $(234-302 \mathrm{~nm})^{20-22}$ are used only for pure active pharmaceutical ingredients assay, because many organic substances absorb light in the same spectrum range. On the other hand, the colored amoxicillin derivatives as analytical forms for AM spectrophotometric determination are often obtained using the azo-coupling reaction. In particular, the spectrophotometric methods of AM determination, which are based on their reaction with diazotized $p$-aminobenzene acid and procaine, ${ }^{23} o$-nitroaniline, ${ }^{24}$ metaclopramid, ${ }^{25}$ benzocaine, ${ }^{26}$ and sulphanilic acid ${ }^{27}$ are known. The spectophotometric methods of the AM determination based on the reactions of chelate and ion-pair complexes formation $^{24,28,29}$ are described. However, many of the known methods of AM determination have a number of disadvantages: long run time, use of organic solvents, and a boiling/ice water bath. All of the above spectrophotometric methods ${ }^{23-29}$ of AM determination were used only for the analysis of pharmaceutical formulations. Moreover, many of the described spectrophotometric methods for AM determination are not validated, although it is required by most world's pharmacopoeia. Among the validated ones are mainly the methods based on measuring their own absorbance in the UV spectrum range.

The azo-coupling reaction is important both for the analysis and the synthesis of new organic substances. Since azo-coupling is widely used for the spectrophotometric AM determination, sulphanilamides can be promising and easily available analytical reagents. They are derivatives of sulphanilic acid, which are able to depress the development of Gram-positive and Gram-negative bacteria, some protozoons and pathogenic fungi. The acidic properties of the sulphamide group make it possible to interact with the salts of heavy metals. In this case, colored complexes, soluble or insoluble in water, are formed..$^{30}$ Besides, due to the presence of the primary aromatic amino group, the sulphanilamides enter into a diazotization reaction with the next azo-coupling with various phenolic compounds. In particular, we have previously studied the conditions for sulphanilamides diazotization and their subsequent azo copling with hydroxy-substituted azo compounds, namely,

Table 2. Structural formula and some characterstics of investigated sulphanilamides

\begin{tabular}{|c|c|}
\hline \multicolumn{2}{|l|}{ Reagent } \\
\hline $\begin{array}{l}\text { Sulphanil } \\
p \text {-aminob }\end{array}$ & dum \\
\hline $\mathrm{H}_{2} \mathrm{~N}-\underset{\mathrm{O}}{\mathrm{O}}$ & $\begin{array}{l}M=172.2 \mathrm{~g} \times \mathrm{mol}^{-1} \\
\mathrm{p} K_{\mathrm{a} 1} \mathrm{NA} ; \mathrm{p} K_{\mathrm{a} 2}=10.1 \\
\log K_{\mathrm{ow}}=-0.62\end{array}$ \\
\hline
\end{tabular}

Sulphathiazole (STZ),

2-(p-aminobenzenesulfonamido)-1,3-thiazol,

CAS 72-14-0

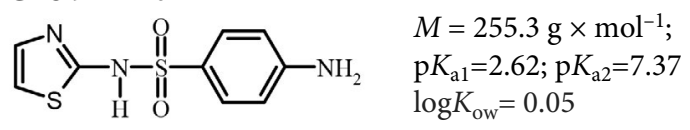

NA - not available

\section{Characteristics}

Appearance: white crystalline powder. It is odorless, slightly bitter with a sweet after-taste.

Solubility: highly soluble in boiling water (1:2), hardly in ethanol (1:37), soluble in solutions of hydrochloric acid, caustic alkalis, acetone (1:5), glycerol, propylene glycols; practically insoluble in ether, chloroform, benzene, petroleum ether.

Appearance: white or white with a slightly yellowish tint, odorless crystalline powder.

Solubility: very slightly soluble in water, slightly soluble in ethanol, soluble in dilute mineral acids and alkaline solutions. 
with the acid monoazo dye Tropaeolin $\mathrm{O}(\mathrm{TrO})^{30,31}$ and heterocyclic azo reagents 4-(2-pyridylazo)-resorcinol ${ }^{30,32}$ (PAR) and 4-(2-thiazolylazo)-resorcinol (TAR). ${ }^{30,33}$ The absorbance maxima of the obtained nitroso disazo compounds at the spectrum range $590-620 \mathrm{~nm}^{30-33}$ have been successfully used for the sulphanilamides determination in dosage forms.

Sulphanilamides are not used as reagents. In our investagtion the simple members of this class, sulphanilamide and sulphathiazole (Table 2), were explored as reagents for the first time.

\section{Materials and Methods}

\section{1. Apparatus}

UV-VIS measurements were performed with UVVIS scanning spectrophotometer SPECORD M-40 (Carl Zeiss Jena, Germany) using $1 \mathrm{~cm}$ cuvettes. All absorbance measurements were performed at $20-25^{\circ} \mathrm{C}$.

The $\mathrm{pH}$ value was measured by $\mathrm{pH}$-meter model pH 150M (Gomelsky Plant of Measuring Devices, Belarus), equipped with a combination electrode, which incorporates both glass and reference silver chloride electrodes into one body. The required $\mathrm{pH}$ of each solution was adjusted using diluted $\mathrm{HCl}$ and $\mathrm{NaOH}$ solutions.

\section{2. Reagents}

All aqueous solutions were prepared using distilled water.

Solutions of amoxicillin (Sigma-Aldrich, Germany) were prepared by dissolving the appropriate amounts of the reagent of pharmacopoeia grade $(\geq 99 \%)$ in a $0.1 \mathrm{M}$ $\mathrm{HCl}$ solution. The working solutions were stored at a room temperature in a dark place no longer than two days.

Sulphanilamides (SA, STZ) were purchased from Sigma (USA). Solutions of sulphanilamide and sulphathiazole were prepared by dissolving appropriate amounts of the reagents of pharmacopoeia grade in $0.1 \mathrm{M}$ sodium hydroxide solution. Solutions of amoxicillin were prepared by dissolving appropriate amounts of the reagent of pharmacopoeia grade in $0.1 \mathrm{M}$ hydrochloric acid. All solutions were stored at a room temperature in a dark place.

The solutions of hydrochloric acid, phosphoric acid, acetic acid, boric acid, sodium hydroxide, sodium nitrite, sodium tetraborate, sodium acetate, sodium phosphate, sodium pyrophosphate, and sodium carbonate, were prepared from chemicals of the analytical grade.

\section{3. Procedure}

\section{Procedure for tablets or powder preparation for the AM determination}

Twenty tablets were weighed and finely powdered in a porcelain mortar. The accurate amount of powder, con- taining $250 \mathrm{mg} \mathrm{AM}$, was placed into a $50 \mathrm{~mL}$ volumetric flask and was dissolved in $25 \mathrm{~mL} 0.1 \mathrm{M} \mathrm{HCl}$ for obtaining AM extract. Then solution was mixed for $60 \mathrm{~min}$ and $0.1 \mathrm{M} \mathrm{HCl}$ was added to complete the volume to $50 \mathrm{~mL}$. Obtained solution was mixed again and was filtered through the folded filter of medium porosity. The filtrate was 10 -fold diluted. Furthermore $5.0 \mathrm{~mL}$ of filtrate was placed into a $50 \mathrm{~mL}$ volumetric flask and diluted with $0.1 \mathrm{M} \mathrm{HCl}$ solution to the full volume $50 \mathrm{~mL}$. Nominal AM content in solution obtained in such way was $250 \mu \mathrm{g} \times$ $\mathrm{mL}^{-1}$. For the assay an aliquot of $1 \mathrm{~mL}$ of the solution was taken and then treated as described below in the recommended procedure for the amoxicillin determination.

\section{General procedure of $\mathrm{AM}$ determination with $\mathrm{SA}$ and STZ}

$5.0 \mathrm{~mL}$ of $0.6 \mathrm{M}$ or $0.7 \mathrm{M}$ hydrochloric acid solution was placed into a $25 \mathrm{~mL}$ volumetric flask, then $2.0 \mathrm{~mL} 5.5$ $\cdot 10^{-3} \mathrm{M}$ SA or $4.5 \cdot 10^{-3} \mathrm{M}$ STZ were added, respectively. Next, $1.75 \mathrm{~mL} 0.1 \mathrm{M}$ sodium nitrite solution was added into the flask. Obtained solution was stirred and allowed to stand for $20 \mathrm{~min}$ at a room temperature. Then sample of amoxicillin solution containing $1.3-32.9 \mu \mathrm{g} \times \mathrm{mL}^{-1}$ (in the method with sulphanilamide) or $0.7-27.4 \mu \mathrm{g} \times \mathrm{mL}^{-1}$ (in the method with sulphathiazole) of AM (in the final volume) was added. Then $10.0 \mathrm{~mL} 0.25 \mathrm{M}$ sodium tetraborate solution was added, next the obtained mixture was neutralized by adding $3.0 \mathrm{~mL} 2.0 \mathrm{M}$ sodium hydroxide solution and the $\mathrm{pH}$ value was adjusted to $\mathrm{pH}=10.5$ and distilled water was added to the full volume $25 \mathrm{~mL}$. Then the solution was mixed thoroughly and the absorbance measurements (at the room temperature $\sim 20{ }^{\circ} \mathrm{C}$ ) were carried out against all corresponding reagents blank solution at $445 \mathrm{~nm}(\mathrm{AM}+\mathrm{SA})$ and $448 \mathrm{~nm}(\mathrm{AM}+\mathrm{STZ})$ in $1.0 \mathrm{~cm}$ cuvettes. Amoxicillin concentration was calculated using the methods of calibration curve and single-point calibration.

\section{Results and Discussion}

\section{1. Absorption Spectra}

The conditions of amoxicillin interaction with sulphanilamide and sulphathiazole have been studied.

Experimental data revealed that AM does not directly interact with sulphanilamides. However, diazonium salts of SA and STZ azo-couple with AM and form colored azo compounds. As follows from their absorption spectra, new absorbance maxima at $\lambda_{\max }=445 \mathrm{~nm}$ and $\lambda_{\max }=448 \mathrm{~nm}$ appear, respectively (Fig. 1), the absorbance value of which linearly depends on the AM concentration. These maxima are not characteristic for the absorption spectrum of the amoxicillin own absorbance in the alkaline medium $\left(\lambda_{\max }=250 \mathrm{~nm}\right)$, nor for diazotized reagents in the alkaline medium: $\lambda_{\max }=263 \mathrm{~nm}$ for SA and $\lambda_{\max }=265 \mathrm{~nm}$ for STZ. However, in the case of diazotized STZ compared to SA in 

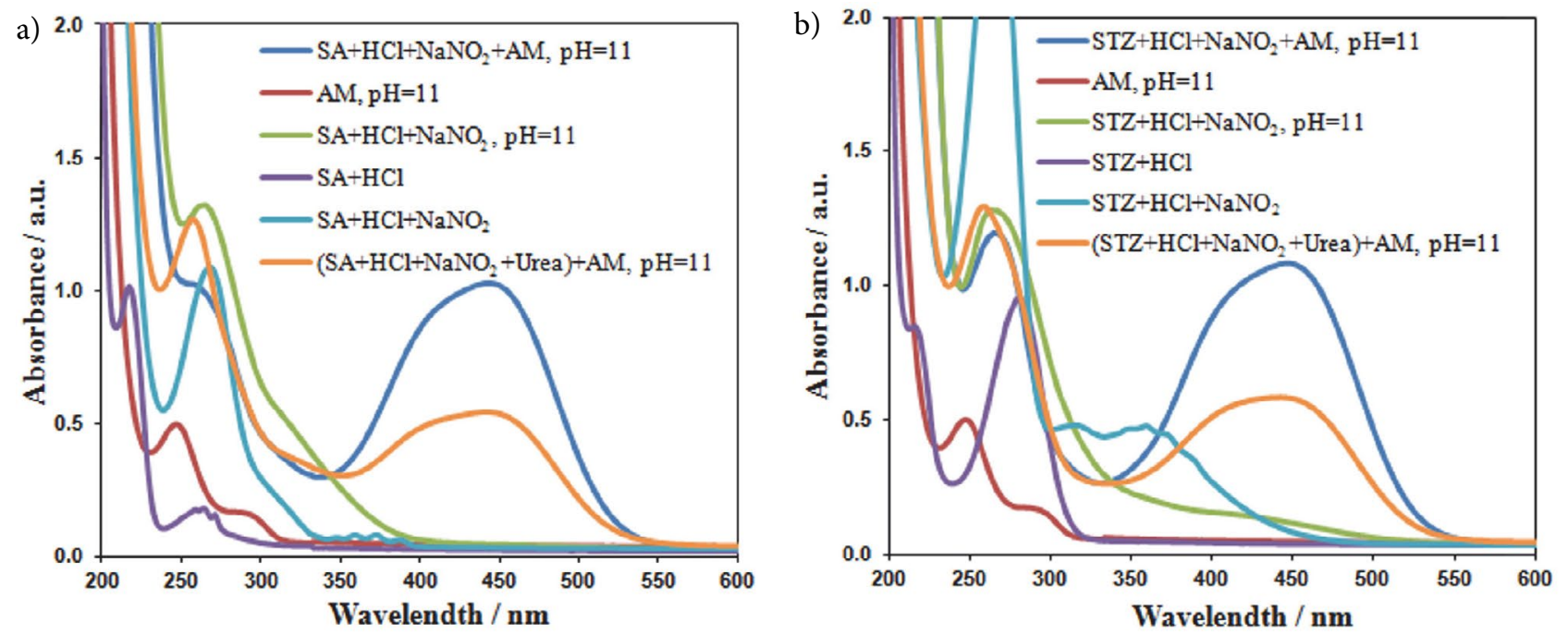

Fig. 1. Absorption spectra of aqueous solutions of $\mathrm{AM}$ interaction products with a) $\mathrm{SA}$ and b) $\mathrm{STZ}$ diazonium salt. $\mathrm{C}_{\mathrm{SA}}=1.0 \cdot 10^{-4} \mathrm{M}, \mathrm{C}_{\mathrm{STZ}}=1.0$. $10^{-4} \mathrm{M}, \mathrm{C}_{\mathrm{AM}}=5.0 \cdot 10^{-5} \mathrm{M}, \mathrm{C}_{\mathrm{NaNO}_{2}}=1.0 \cdot 10^{-3} \mathrm{M}, \mathrm{C}_{\mathrm{HCl}}=1.0 \mathrm{M}$.

the alkaline medium, a negligible absorbance is observed at $440-450 \mathrm{~nm}$ due to the azo compound, which is probably slowly formed by the diazotized STZ's own azo-coupling. This compound has a stronger chromophore system due to the presence of sulphathiazole heterocycle substituent in the sulphanilamide molecule. Though, in subsequent studies, the effect of the competing reaction of the<smiles>[R]c1ccc(N)cc1</smiles>

1<smiles>[R]c1ccc(C#[N+])cc1</smiles>
$-\mathrm{H}_{2} \mathrm{O} \downarrow+\mathrm{OH}^{-}$<smiles>[Y]c1ccc(N=Nc2cc([C@@H](N)C(=O)N[C@H]3C(=O)N4C(C(=O)O)C(C)(C)S[C@H]34)ccc2O)cc1</smiles>

4<smiles>[R]S(N)(=O)=O</smiles>

Scheme 1. Scheme of amoxicillin interaction with sulphanilamide and sulphathiazole diazotized STZ's own azo-coupling is compensated, since all measurements were made versus blank solution. In addition, the broad absorbance maxima in the spectrum range $250-270 \mathrm{~nm}$ (Fig. 1) are observed on the absorption spectra of both obtained products as a result of the additive absorbance of the fragments of both reagents in the newly formed products.

As follows from the absorption spectra (Fig. 1), it is inappropriate to destroy the excess of unreacted nitrite ions during the SA and STZ diazotization using urea, since the absorbance of their azo-coupling products with AM is significantly reduced.

The obtained water soluble colored products of AM interaction with the diazotized SA and STZ are used for the quantitative determination of amoxicillin (Scheme 1).

Nitrite-ions diazotize primary aromatic amino group of the reagent (SA, STZ) (1) in acid media with the formation of the corresponding diazonium salt (2), which interacts with AM in alkaline media to form yellow-colored product (4).

\section{2. Conditions of Sulphanilamides Diazotization}

\section{2. 1. Effect of Acid Nature and Concentration}

According to literary sources the primary aromatic amino group, which is included in the structure of the investigated reagents, is diazotized in a strongly acidic medi$\mathrm{um}^{34}$ and the nature of the acid affects the yield of the following azo-coupling reaction product.

The conditions of SA diazotization described in the literature are rather contradictory (either hydrochloric acid in the concentration range from $0.1 \mathrm{M}^{35}$ to $5 \mathrm{M}^{36-38}$ or $10 \mathrm{M}$ sulfuric acid ${ }^{39}$ or a mixture of phosphoric and acetic acid $^{40}$ is used), therefore we have investigated the influ- 

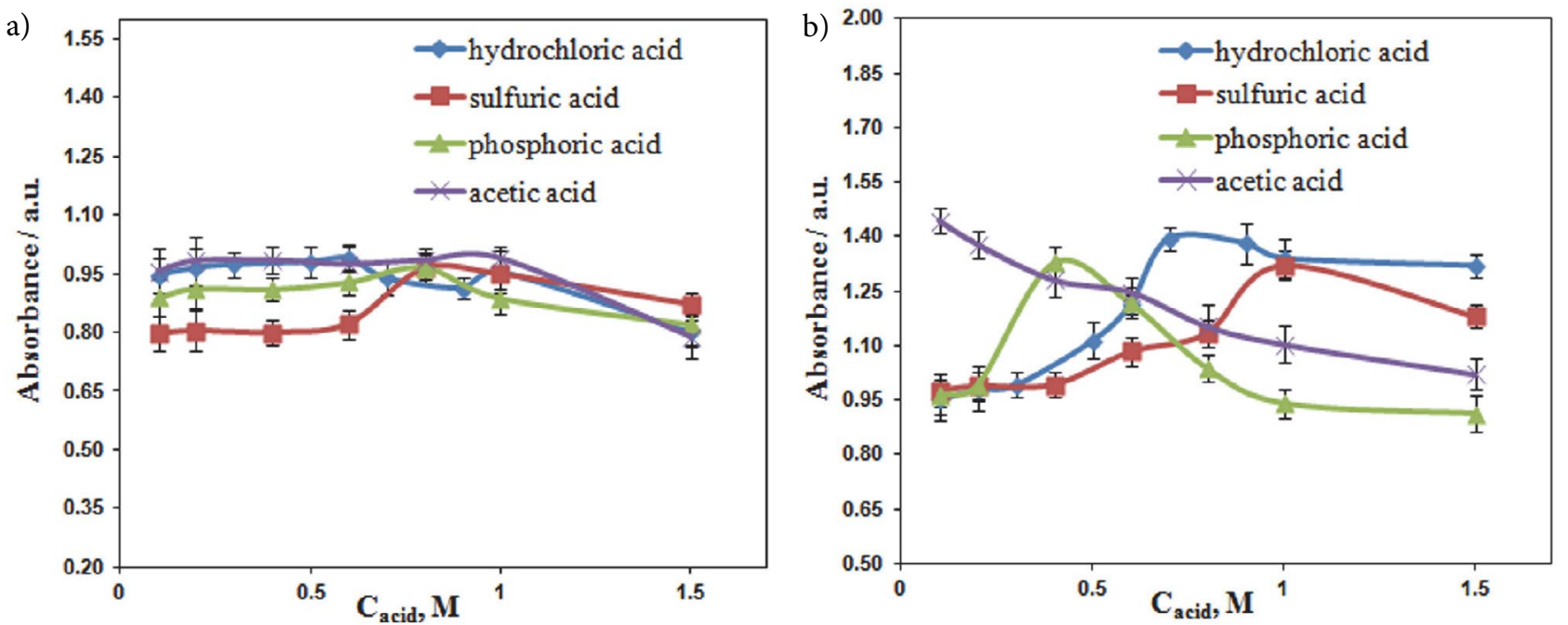

Fig. 2. Effect of nature and concentration of acid on the a) SA and b) STZ diazonium salt formation and the product of its interaction with the AM. $\mathrm{C}_{\mathrm{SA}}=2.0 \cdot 10^{-4} \mathrm{M}, \mathrm{C}_{\mathrm{STZ}}=2.0 \cdot 10^{-4} \mathrm{M}, \mathrm{C}_{\mathrm{NaNO}_{2}}=2.0 \cdot 10^{-3} \mathrm{M}, \mathrm{C}_{\mathrm{AM}}=5.0 \cdot 10^{-5} \mathrm{M}, \mathrm{n}=5$.

ence of hydrochloric, sulfuric, phosphoric, and acetic acid concentration on the SA and STZ diazonium salts yield and the following formation of their azo-coupling products with AM.

As follows from the experimental data (Fig. 2), the maximum efficiency of the products of AM interaction with SA and STZ diazonium salts is observed at SA diazotization in acetic acid medium but the use of hydrochloric acid allows to achieve a comparative yield of diazonium salts and azo-coupling products, therefore, we chose $0.6 \mathrm{M}$ and 0.7 M hydrochloric acid for the SA and STZ diazotization, respectively. The differences can be caused by different acids strength as well as by different intermediates activity, which are formed during the SA diazotization. According to the mechanism of diazotization, the reaction occurs in several stages, as a result, depending on the type of the acid used, various diazotizing agents are formed. One of the important steps is the formation of a nitrosyl cation, which at the next stage interacts with a nitrite ion, forming nitrogen(III) oxide, which is the most active diazotizing agent. Depending on the used mineral acid, the actual diazotizing reagent may be nitrosyl chloride, nitrosyl sulfate, nitrosyl acetate, or nitrosyl phosphate, which enter into the next reaction with different activity level. ${ }^{41}$

\section{2. 2. Effect of Sodium Nitrite Concentration and Time of Diazotization}

The influence of sodium nitrite concentration as diazotizing reagent on the yield of sulphanilamide and sulphathiazole diazonium salts, as well as their azo compounds with AM accordingly has been investigated. As it is shown on Fig. 3, optimum for sulphanilamides diazotization is to use more than 15 -fold excess of sodium nitrite towards the concentration of SA and STZ $\left(C_{\text {reagent }}\right.$ : $\left.C_{\mathrm{NaNO}_{2}}=2.0 \cdot 10^{-4} \mathrm{M}: 3.0 \cdot 10^{-3} \mathrm{M}=1: 15\right)$ when the analyti- cal signal does not change with the increase in nitrite ions concentration. The excess sodium nitrite towards the SA is explained by the diazotization mechanism, according to which two molecules of nitric acid interact with one aromatic amino group, ${ }^{34}$ besides, as it is known, the excess of the reagent shifts the reaction equilibrium toward the reaction products.

For obtaining maximal yields of sulphanilamide and sulphathiazole diazonium salts, the effect of time of diazotization was investigated (Fig. 4). The maximal yields of diazonium salts and azo-coupling products with AM have been observed at $20 \mathrm{~min}$ of diazotization of reagents at a room temperature. The further increase of diazotization time did not result in any significant increase of azo com-

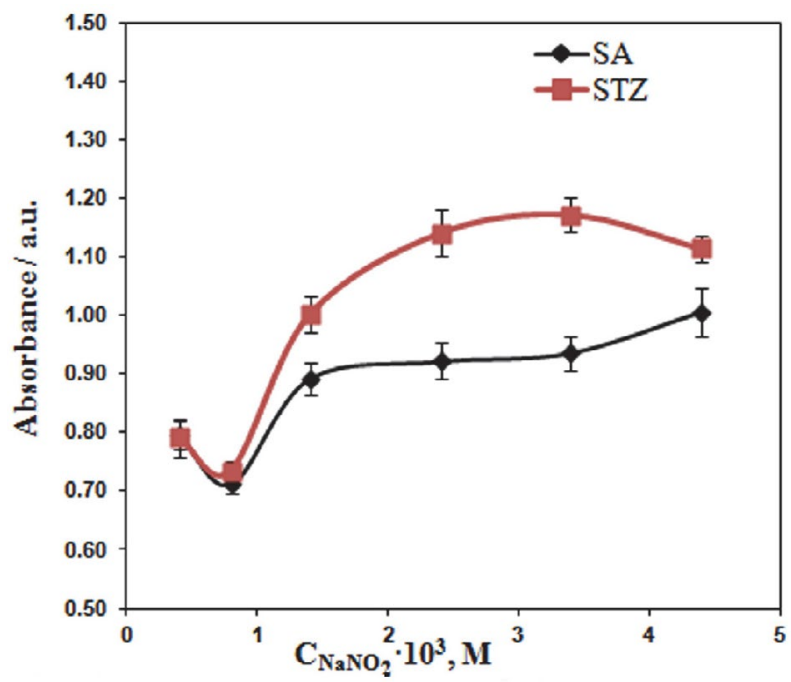

Fig. 3. Effect of sodium nitrite concentration during SA and STZ diazotization on and the SA and STZ interaction with AM. 1. $\mathrm{C}_{\mathrm{SA}}=$ $2.0 \cdot 10^{-4} \mathrm{M}, \mathrm{C}_{\mathrm{HCl}}=0.6 \mathrm{M} ; 2 . \mathrm{C}_{\mathrm{STZ}}=2.0 \cdot 10^{-4} \mathrm{M}, \mathrm{C}_{\mathrm{HCl}}=0.7 \mathrm{M} ; \mathrm{C}_{\mathrm{AM}}$ $=5.0 \cdot 10^{-5} \mathrm{M}, \mathrm{C}_{\mathrm{Na}_{2} \mathrm{~B}_{4} \mathrm{O}_{7}}=0.1 \mathrm{M}, \mathrm{n}=5$. 


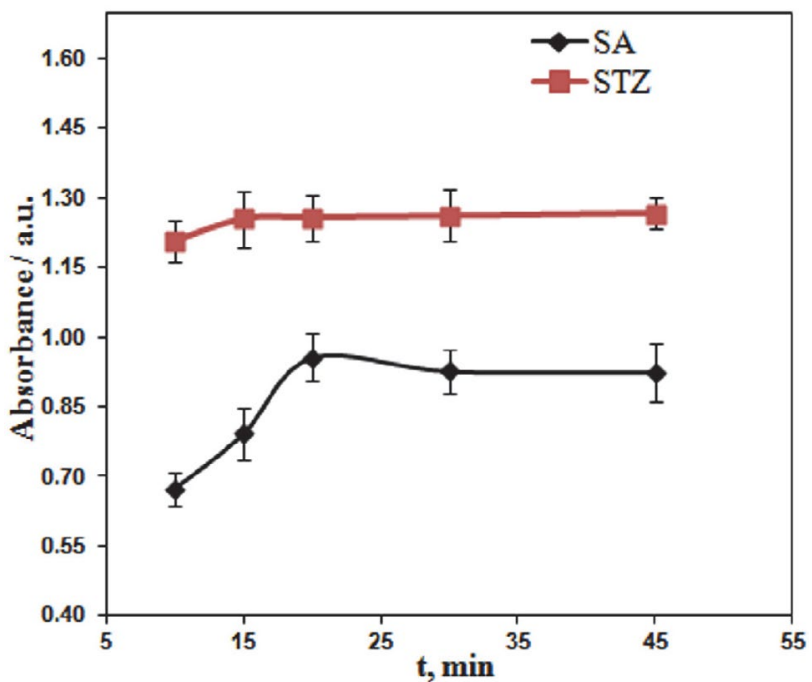

Fig. 4. Effect of time of the SA and STZ diazotization on the yield of the product of theirs interaction with AM. $1 . \mathrm{C}_{\mathrm{SA}}=2.0 \cdot 10^{-4} \mathrm{M}$, $\mathrm{C}_{\mathrm{HCl}}=0.6 \mathrm{M} ; 2 . \mathrm{C}_{\mathrm{STZ}}=2.0 \cdot 10^{-4} \mathrm{M}, \mathrm{C}_{\mathrm{HCl}}=0.7 \mathrm{M} ; \mathrm{C}_{\mathrm{AM}}=5.0 \cdot 10^{-5}$ $\mathrm{M}, \mathrm{C}_{\mathrm{NaNO}_{2}}=3.0 \cdot 10^{-3} \mathrm{M}, \mathrm{C}_{\mathrm{Na}_{2} \mathrm{~B}_{4} \mathrm{O}_{7}}=0.1 \mathrm{M}, \mathrm{n}=5$.

pounds yield, so all following investigations were carried out at a room temperature while duration of diazotization was $20 \mathrm{~min}$.

\section{3. Azo-Coupling Conditions of AM with SA and STZ Diazonium Salts}

\section{3. 1. Effect of $\mathrm{pH}$}

According to the literature review, the diazonium cation is a relatively weak electrophile which can exist only in acidic medium and is reactive with a phenolate ion in an alkaline medium rather than with a weakly dissociated molecular form of phenol. Therefore, an azo-coupling re-

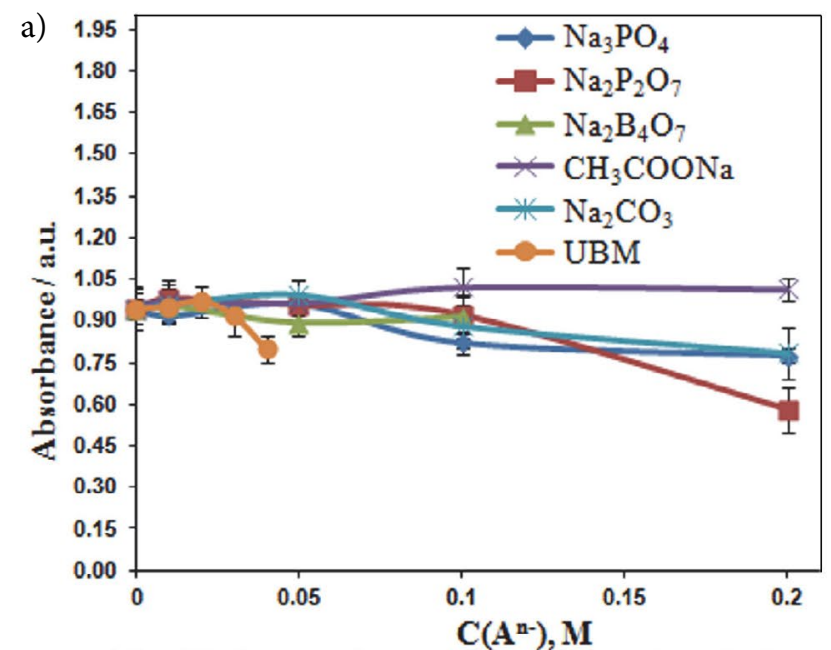

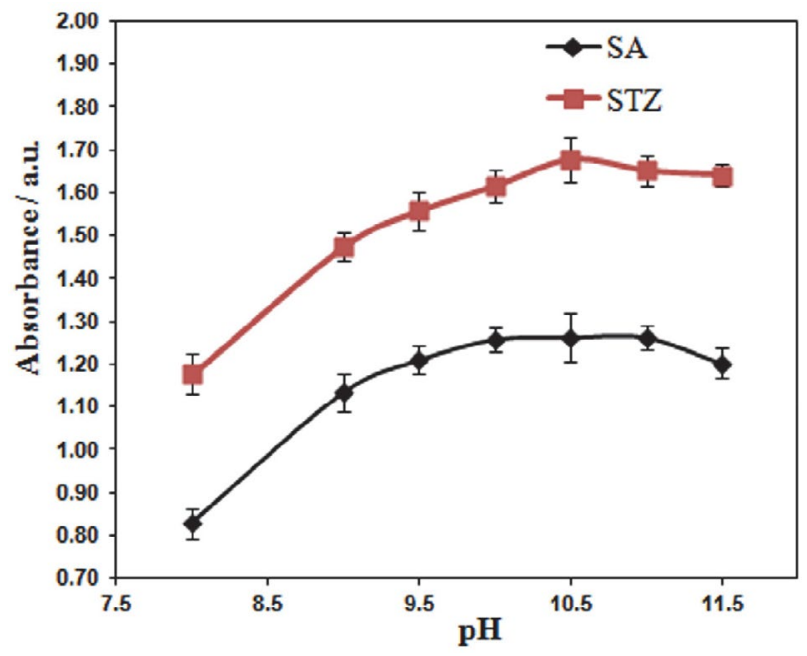

Fig. 5. Effect of medium acidity on SA and STZ diazonium salt azocoupling with AM. 1. $\mathrm{C}_{\mathrm{SA}}=2.0 \cdot 10^{-4} \mathrm{M}, \mathrm{C}_{\mathrm{HCl}}=0.6 \mathrm{M} ; 2 . \mathrm{C}_{\mathrm{STZ}}=2.0$ $\cdot 10^{-4} \mathrm{M}, \mathrm{C}_{\mathrm{HCl}}=0.7 \mathrm{M} ; \mathrm{C}_{\mathrm{NaNO}_{2}}=3.0 \cdot 10^{-3} \mathrm{M}, \mathrm{C}_{\mathrm{AM}}=5.0 \cdot 10^{-5} \mathrm{M}$, $\mathrm{C}_{\mathrm{Na}_{2} \mathrm{~B}_{4} \mathrm{O}_{7}}=0.1 \mathrm{M}, \mathrm{n}=5$.

action between diazonium salt and phenolic compounds occurs in an alkaline medium at $\mathrm{pH} 9-10 .{ }^{34}$

The influence of acidity on the absorbance of the products of diazotized SA and STZ azo-coupling with amoxicillin were investigated to establish the optimal reaction conditions. As it is shown in Fig. 5, the maximal yield of azo compounds is observed at $\mathrm{pH}=10.5$, therefore, we used this $\mathrm{pH}$ value in the next experiments.

The effect of the nature and concentration of various salts anions on the interaction of AM with the tested reagents has been investigated to study the specificity of the developed methods and the selection of a buffer mixture for stabilization of the conditions of the azo-coupling reaction.

According to the experimental results (Fig. 6), the presence of anions with different nature and concentration

Fig. 6. Influence of nature and concentration of salts anions (acetate, pyrophosphate, carbonate, tetraborate, phosphate) and buffer solution (UBM) on the a) SA and b) STZ interaction with AM. $1 . \mathrm{C}_{\mathrm{SA}}=2.0 \cdot 10^{-4} \mathrm{M}, \mathrm{C}_{\mathrm{HCl}}=0.6 \mathrm{M} ; 2 . \mathrm{C}_{\mathrm{STZ}}=2.0 \cdot 10^{-4} \mathrm{M}, \mathrm{C}_{\mathrm{HCl}}=0.7 \mathrm{M}_{;} \mathrm{C}_{\mathrm{NaNO}_{2}}=3.0 \cdot 10^{-3} \mathrm{M}, \mathrm{C}_{\mathrm{AM}}=$ $5.0 \cdot 10^{-5} \mathrm{M}, \mathrm{n}=5$. 
in the solution influence the AM interaction with diazotized reagents. The pyrophosphate and phosphate anions adversely affect the yield of the final product, whereas the use of sodium carbonate slightly increases the analytical signal. The use of sodium tetraborate and universal buffer mixture (UBM: $0.4 \mathrm{M} \mathrm{CH}_{3} \mathrm{COOH}+0.4 \mathrm{M} \mathrm{H}_{3} \mathrm{PO}_{4}+0.4 \mathrm{M} \mathrm{H}_{3} \mathrm{BO}_{3}$ ) solutions at low concentrations allows to stabilize the products absorbance. However, the UBM in higher concentration significantly decreases the analytical signal, while sodium tetraborate at low concentrations practically does not affect its value. Therefore, sodium tetraborate with concentration $0.1 \mathrm{M}$ in the final volume has been used as a buffer solution.

\section{3. 2. Effect of SA and STZ Concentration}

We investigated the effect of reagents excess on the yield of products of AM azo copling with SA and STZ dia-

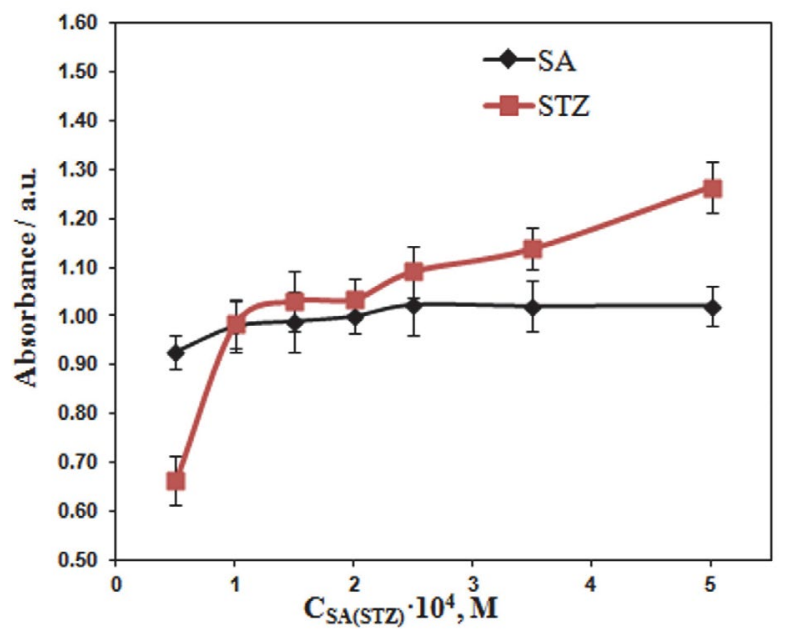

Fig. 7. The mole ratio curve for the product of amoxicillin interaction with SA and STZ diazonium salt. 1. SA $\mathrm{C}_{\mathrm{HCl}}=0.6 \mathrm{M} ; 2$. STZ $\mathrm{C}_{\mathrm{HCl}}=0.7 \mathrm{M} ; \mathrm{C}_{\mathrm{AM}}=5.0 \cdot 10^{-5} \mathrm{M}, \mathrm{C}_{\mathrm{HCl}}=0.6 \mathrm{M}, \mathrm{C}_{\mathrm{Na}_{2} \mathrm{~B}_{4} \mathrm{O}_{7}}=0,1 \mathrm{M}, \mathrm{pH}$ $=10.5, \mathrm{n}=5$.

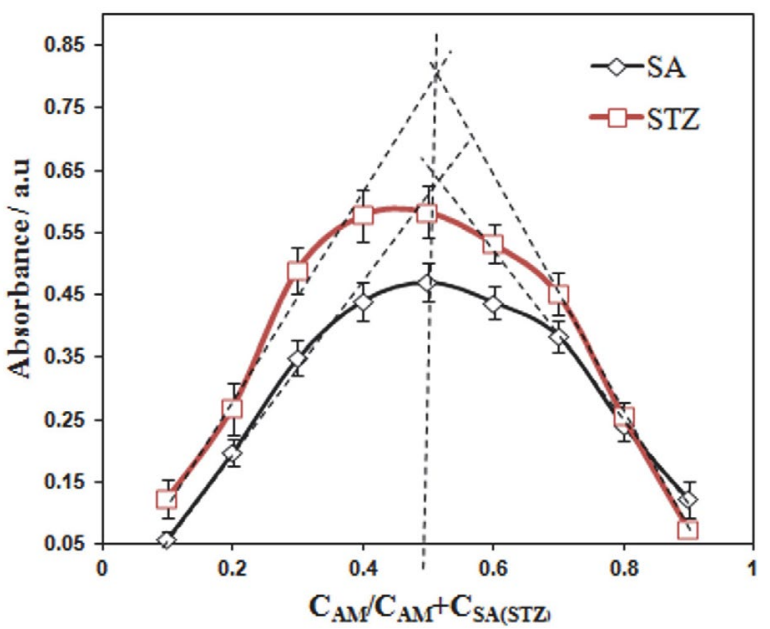

Fig. 8. The method of continuous varations. 1. $\mathrm{C}_{\mathrm{SA}}+\mathrm{C}_{\mathrm{AM}}=3.12$. $10^{-4} \mathrm{M}, \mathrm{C}_{\mathrm{HCl}}=0.6 \mathrm{M} ; 2 . \mathrm{C}_{\mathrm{STZ}}+\mathrm{C}_{\mathrm{AM}}=3.12 \cdot 10^{-4} \mathrm{M}, \mathrm{C}_{\mathrm{HCl}}=0.7 \mathrm{M}$; $\mathrm{C}_{\mathrm{NaNO}_{2}}=5.6 \cdot 10^{-3} \mathrm{M}, \mathrm{C}_{\mathrm{Na}_{2} \mathrm{~B}_{4} \mathrm{O}_{7}}=0.1 \mathrm{M}, \mathrm{pH}=10.5, \mathrm{n}=5$. zonium salts because certain reagents excess promote a shift of reaction equilibrium toward the formation of reaction products. We found that SA and STZ excess towards $\mathrm{AM}$ is required to obtain the maximum yield of the colored analytical forms 5 -fold diazotized reagents, while the increase of SA concentrations does not affect the analytical signal (Fig. 7). The experimental results showed a sharp increase in the analytical signal when 10 -fold excess of STZ diazonium salts for azo-coupling with AM was used. However, at high concentrations STZ diazonium salts can combine together, therefore, the value of products absorbance also can increase, therefore, the application of a large reagent excess is not required.

The method of continuous variations was used to establish the mole ratio of the components in the compounds of diazotized SA and STZ with amoxicillin (Fig. 8). The stoichiometric SA:AM ratios is equal to 1:1 for both tested sulphanilamides, which indicates the reaction of the azo-coupling of SA and STZ diazonium salts as diazo component with amoxicillin as coupling component to form azo compounds.

The procedure for introducing reagents into the reaction mixture has a significant effect on the yield of colored products. The maximal absorbance of obtained azo compounds is observed if reagents are added in the following sequence. The solution of hydrochloric acid, SA or STZ solution, and sodium nitrite solution are added first. Next, SA diazotization is carried out and only then AM and buffer solutions are added. Finally, the $\mathrm{pH}$ of mixture is adjusted to the required value by adding sodium hydroxide solution.

The stability of the analytical form is extremely important for reliable measurement during the assay. Therefore, the stability of absorbance of obtained azo-coupling products of diazotized SA and STZ with amoxicillin was investigated and the results are shown on Fig. 9. The absor-

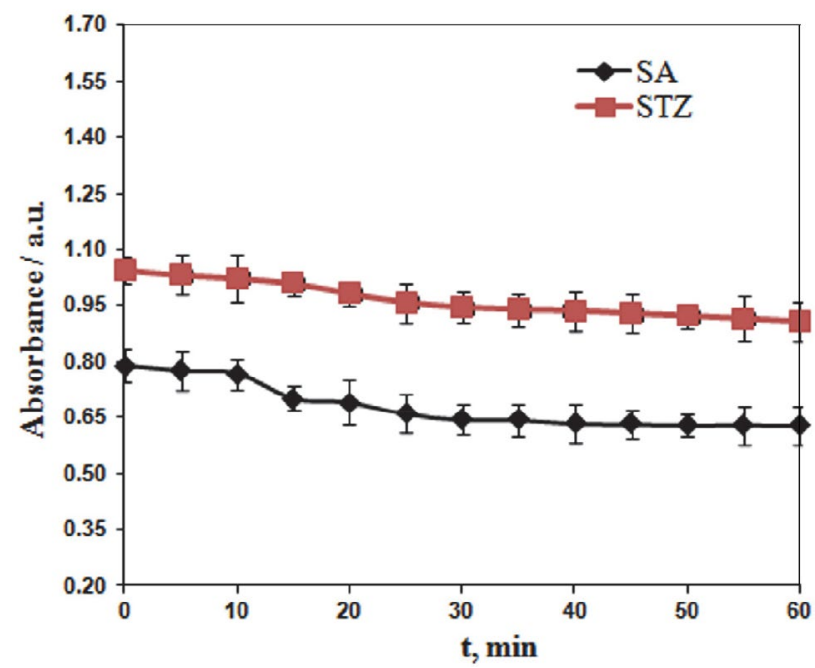

Fig. 9. Effect of the keeping time on the absorbance of azocoupling product of diazotized SA and STZ with AM. $1 . \mathrm{C}_{\mathrm{SA}}=2.0 \cdot 10^{-4} \mathrm{M}$, $\mathrm{C}_{\mathrm{HCl}}=0.6 \mathrm{M} ; 2 . \mathrm{C}_{\mathrm{STZ}}=1.9 \cdot 10^{-4} \mathrm{M}, \mathrm{C}_{\mathrm{HCl}}=0.7 \mathrm{M} ; \mathrm{C}_{\mathrm{NaNO}_{2}}=3.0 \cdot 10^{-3}$ $\mathrm{M}, \mathrm{C}_{\mathrm{AM}}=3.75 \cdot 10^{-5} \mathrm{M}, \mathrm{C}_{\mathrm{Na}_{2} \mathrm{~B}_{4} \mathrm{O}_{7}}=0.1 \mathrm{M}, \mathrm{pH}=10.5, \mathrm{n}=5$. 
bance value of examined azo compounds did not change for $10 \mathrm{~min}$, which is sufficient for the assay (Fig. 9). However, it should be noted that after $20 \mathrm{~min}$ the absorbance of solutions of all products slightly decreases, then stabilizes and remains stable for $1 \mathrm{~h}$.

\section{4. Analytical Characteristics of the Developed Method}

The new spectrophotometric method of AM determination has been developed based on the optimal condi- tions of AM interaction with SA and STZ. The absorbance of colored products in systems SA-AM and STZ-AM linearly depends on AM concentration in the solution. Analytical characteristics of AM determination are presented in Table 3.

Characteristics of some available published spectrophotometric methods for the amoxicillin determination are presented in Table 4.

Thus, the elaborated methods for the spectrophotometric determination of amoxicillin with SA and STZ posses wide linear ranges (almost two orders of concentra-

Table 3. Analytical characteristics of the formed azo compound and validation results of AM spectrophotometric determination with SA and STZ. $C_{\mathrm{HCI}}=0.6 \mathrm{M}, C_{\mathrm{SA}}=4.5 \cdot 10^{-4} \mathrm{M}, C_{\mathrm{NaNO}_{2}}=$ $7.2 \cdot 10^{-3} \mathrm{M}, C_{\mathrm{HCI}}=0.7 \mathrm{M}, C_{\mathrm{STZ}}=3.6 \cdot 10^{-4} \mathrm{M}, C_{\mathrm{NaNO}_{2}}=5.6 \cdot 10^{-3} \mathrm{M}, C_{\mathrm{Na}_{2} \mathrm{~B}_{4} \mathrm{O}_{7}}=0.1 \mathrm{M}, \mathrm{pH}=10.5$, $l=1 \mathrm{~cm}, P=0.95, n=5$.

\begin{tabular}{lcc}
\hline Parameters/ Characteristics & AM + SA & AM + STZ \\
\hline$\lambda_{\text {max }}, \mathrm{nm}$ & 445 & 448 \\
Stability, $\mathrm{h}$ & 10 & 10 \\
Optimum photometric linear range, $\mu \mathrm{g} \times \mathrm{mL}^{-1}$ & $1.3-32.9$ & $0.7-27.4$ \\
Limit of Quantification, $\mu \mathrm{g} \times \mathrm{mL}^{-1}$ & 1.32 & 0.76 \\
Limit of Quantification, $\mathrm{M} \times 10^{5}$ & 0.36 & 0.21 \\
Limit of Detection, $\mu \mathrm{g} \times \mathrm{mL}^{-1}$ & 0.40 & 0.23 \\
Limit of Detection, $\mathrm{M} \times 10^{5}$ & 0.11 & 0.06 \\
Molar absorptivity, $\boldsymbol{\varepsilon}_{\lambda \max } \times 10^{-4}, \mathrm{~L} \times \mathrm{mol}^{-1} \times \mathrm{cm}^{-1}$ & $1.74 \pm 0.06$ & $1.97 \pm 0.05$ \\
Regression equation $(A)^{\mathrm{a}}$ slope $(\mathrm{b})$ & 0.059 & 0.056 \\
$\Delta \mathrm{b}$ & 0.006 & 0.003 \\
Intercept $(\mathrm{a})$ & -0.077 & 0.043 \\
$\Delta$ a & 0.136 & 0.034 \\
Correlation coefficient $(R)$ & 0.9987 & 0.9990 \\
\hline \multicolumn{2}{c}{$\mathrm{a} A=\mathrm{b} C+\mathrm{a}$, where $C$ is the concentration of sulphanilamides $\left(\mathrm{SA}\right.$ and STZ) in $\mu \mathrm{g} \times \mathrm{ml}^{-1}}$.
\end{tabular}

Table 4. Spectrophotometric methods for the AM determination using reaction of azo-coupling

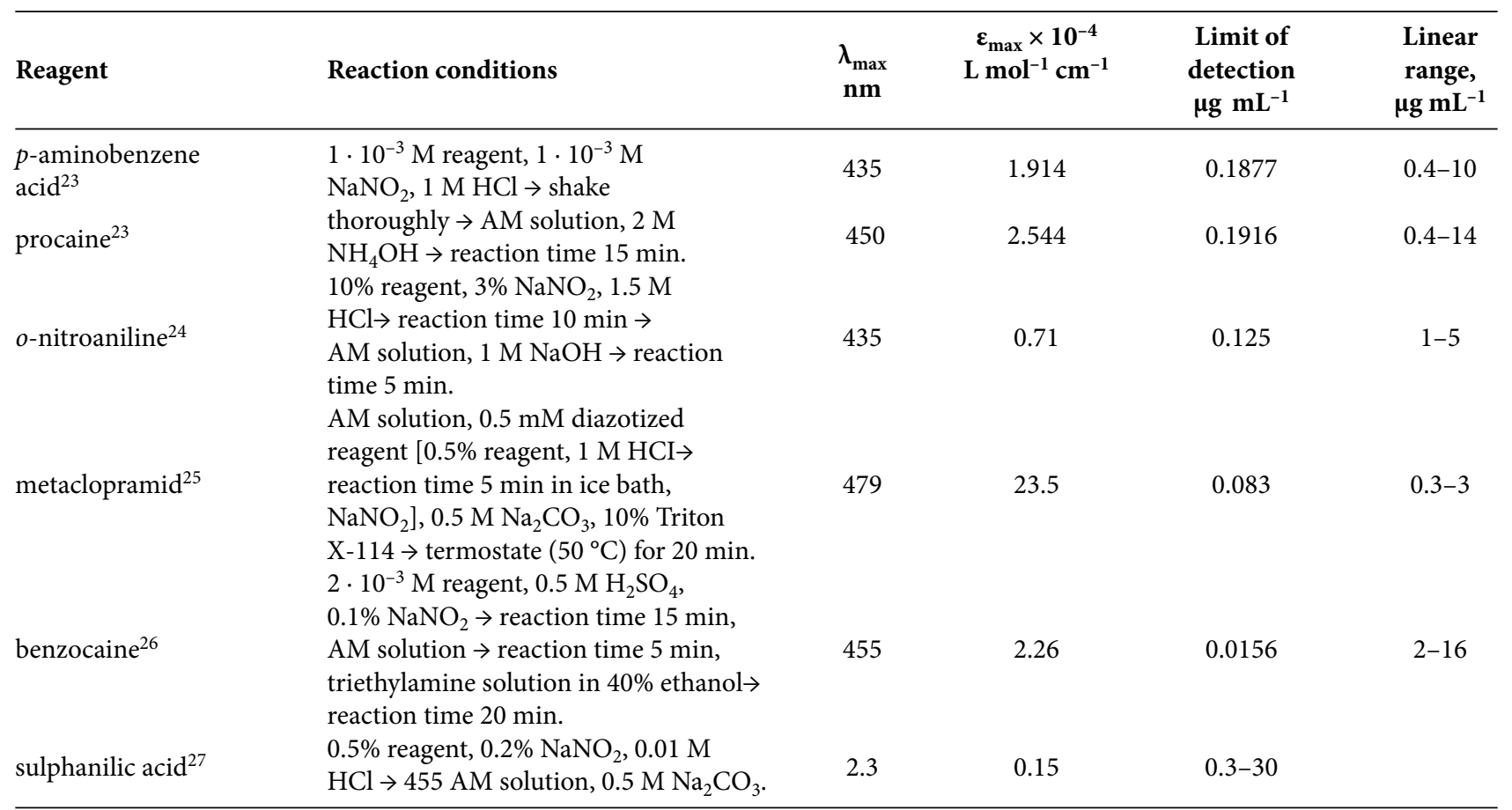


tion); they are simple, rapid and sensitive. Sensitivity of amoxicillin determination with sulphathiazole is comparable to some sensitive spectrophotometric methods of AM determination (Table 4) and in both cases it is close to most spectrophotometric methods. Our proposed methods do not require the use of an ice bath, the temperature control, or organic solvent and are more rapid when compared to some of the methods presented in Table 4. Additionaly, it should be noted that most methods listed in Table 4 were not validated.

\section{5. Analysis of Pharmaceutical Preparations for the AM Content Determination with SA and STZ}

Drugs products containing amoxicillin are released in dosage form of tablets and injection solutions. The natural and synthetic excipients are used for obtaining these dosage forms. The excipients are subdivided into fillers, preservatives, and stabilizers, which usually do not affect the bioactive substances, but may interfere with their determination due to reactions with various reagents. Since a part of amoxicillin dosage forms are combined medicinal products, which besides AM contain other bioactive ingredients, the effect of bioactive substances and common pharmaceutical excipients on the procedure of AM determination by means of SA and STZ was investigated.

Moreover, the selectivity of the developed method was tested for mixtures containing excipients in amounts greatly exceeding their possible content in pharmaceutical preparations. Variability of absorbance value for formed azo compouds SA-AM and STZ-AM in the range $\pm 5 \%$ was chosen as the selectivity criterion of AM determination. The research results are presented in Table 5.

The examined excipients and bioactive substance clavulanic acid, which are present in drugs products, do

Table 5. Effect of excipients on the AM assays by SA and STR. $C_{\mathrm{HCI}}=0.6 \mathrm{M}, C_{\mathrm{SA}}=4.5 \cdot 10^{-4} \mathrm{M}, C_{\mathrm{NaNO}_{2}}=7.2 \cdot 10^{-3} \mathrm{M}, C_{\mathrm{HCI}}=0.7 \mathrm{M}, C_{\mathrm{STZ}}=3.6 \cdot 10^{-4}$ $\mathrm{M}, C_{\mathrm{NaNO}_{2}}=5.6 \cdot 10^{-3} \mathrm{M}, C_{\mathrm{AM}}=3,75 \cdot 10^{-5} \mathrm{M}, C_{\mathrm{Na}_{2} \mathrm{~B}_{4} \mathrm{O}_{7}}=0.1 \mathrm{M}, \mathrm{pH}=10.5, l=1 \mathrm{~cm}, P=0.95, n=5$

\begin{tabular}{|c|c|c|c|c|}
\hline Excipient (Exp) & $\begin{array}{l}m(\mathrm{AM}): \\
m(\mathrm{Exp})^{*}\end{array}$ & $\begin{array}{l}m(\mathrm{AM}): \\
m(\mathrm{Exp})^{* *}\end{array}$ & $\begin{array}{c}\mathbf{S A}+\mathbf{A M} \\
\text { \% Recovery of } \mathbf{A M} \\
\bar{x} \pm S \cdot t_{\alpha} / \sqrt{n}\end{array}$ & $\begin{array}{c}\text { STZ+AM } \\
\text { \% Recovery of AM, } \\
\bar{x} \pm S \cdot t_{\alpha} / \sqrt{n} \\
\end{array}$ \\
\hline Clavulanic acid & $1: 0.25$ & $1: 0.30$ & $96.4 \pm 2.0$ & $100.6 \pm 1.9$ \\
\hline Calcium stearate $e^{* * *}$ & $1: 0.015$ & $1: 10$ & $99.6 \pm 1.9$ & $98.9 \pm 2.1$ \\
\hline Povidone ${ }^{* * *}$ & 1:0.03 & $1: 50$ & $100.4 \pm 1.6$ & $100.1 \pm 1.6$ \\
\hline Sodium Starch Glycolate Type A** & $1: 0.47$ & $1: 10$ & $96.4 \pm 1.9$ & $97.2 \pm 1.5$ \\
\hline Sodium benzoate & $1: 0.003$ & $1: 100$ & $99.5 \pm 1.4$ & $94.5 \pm 1.2$ \\
\hline $\operatorname{Starch}^{* * *}$ & $1: 0.5$ & $1: 50$ & $100.4 \pm 1.4$ & $100.1 \pm 2.0$ \\
\hline Butylated hydroxytoluene & $1: 0.007$ & $1: 10$ & $95.5 \pm 1.6$ & $97.8 \pm 1.5$ \\
\hline Aluminum monostearate ${ }^{* * *}$ & $1: 0.1$ & $1: 2$ & $99.2 \pm 2.0$ & $99.6 \pm 1.8$ \\
\hline Benzyl alcohol & $1: 0.07$ & $1: 0.5$ & $95.4 \pm 2.0$ & $96.4 \pm 2.1$ \\
\hline Coconut oil $^{* *}$ & $1: 0.007$ & 1:0.007 & $94.6 \pm 2.1$ & $94.2 \pm 2.3$ \\
\hline
\end{tabular}

* - mass ratios of AM and excipients, which are present in tested drugs products ** maximum mass ratios of AM and excipients examined $* * *$ - these substances were insoluble at the experimental conditions. For testing they were pre-mixed with AM and dissolved in $0.1 \mathrm{M}$ hydrochloric acid. Insoluble excipients were filtered from AM extract by the same procedure as for the tablets analysis.

Table 6. Determination of $\mathrm{AM}$ in pharmaceuticals. $C_{\mathrm{HCI}}=0.6 \mathrm{M}, C_{\mathrm{SA}}=4.5 \cdot 10^{-4} \mathrm{M}, C_{\mathrm{NaNO}_{2}}=7.2 \cdot 10^{-3} \mathrm{M}, C_{\mathrm{HCI}}=0.7 \mathrm{M}, C_{\mathrm{STZ}}=3.6 \cdot 10^{-4} \mathrm{M}, C_{\mathrm{NaNO}}$ $=5.6 \cdot 10^{-3} \mathrm{M}, C_{\mathrm{Na}_{2} \mathrm{~B}_{4} \mathrm{O}_{7}}=0.1 \mathrm{M}, \mathrm{pH}=10.5, l=1 \mathrm{~cm}, P=0.95, n=5$

\begin{tabular}{|c|c|c|}
\hline \multirow{2}{*}{$\begin{array}{l}\text { Determined AM } \\
\text { (regulated content } \\
\text { in preparation) }\end{array}$} & \multicolumn{2}{|c|}{$\begin{array}{l}\text { Amount of found AM } \bar{x} \pm S \cdot t_{\alpha} / \sqrt{n} \\
\text { and relative standard deviation }\left(S_{\mathrm{r}}\right)\end{array}$} \\
\hline & $\begin{array}{c}\text { Spectrophotometric method } \\
\text { with SA }\end{array}$ & $\begin{array}{c}\text { Spectrophotometric method } \\
\text { with STZ }\end{array}$ \\
\hline \multicolumn{3}{|c|}{$\begin{array}{l}\text { "Amoxil" tablets, Corporation "Arterium", JSC “Kyivmedpreparat", Ukraine } \\
\text { (excipients - povidone, sodium starch glycolate Type A, calcium stearate) }\end{array}$} \\
\hline $\begin{array}{c}\text { Amoxicillin } \\
(250 \pm 12.5 \mathrm{mg} / \mathrm{tabl})\end{array}$ & $\begin{array}{l}260.4 \pm 1.6 \\
(0.005)\end{array}$ & $\begin{array}{l}256.4 \pm 4.7 \\
(0.016)\end{array}$ \\
\hline \multicolumn{3}{|c|}{$\begin{array}{c}\text { "Amoksiklav Quicktab" tablets, Sandoz, Lek Pharmaceutical Company D.D., Slovenia } \\
\text { (Clavulanic acid (1255 mg/tabl), excipients - aspartame (E 951), iron oxide yellow (E172), talc, } \\
\text { cellulose, silicium dioxide) }\end{array}$} \\
\hline $\begin{array}{c}\text { Amoxicillin } \\
(500 \pm 25.0 \mathrm{mg} / \mathrm{tabl})\end{array}$ & $\begin{array}{l}512.5 \pm 8.3 \\
\quad(0.014)\end{array}$ & $\begin{array}{c}510.3 \pm 5.9 \\
(0.010)\end{array}$ \\
\hline
\end{tabular}


not interfere with the AM determination by the developed method with SA and STZ.

The results of $A M$ determination in these products are given in Table. 6. The AM content in tablets "Amoxil" and "Amoksiklav Quicktab" obtained by the developed method using SA and STZ correlates rather well with the content of the AM specified by the manufacturer (with acceptable $5 \%$ deviation from regulated content). The high performance liquid chromatography is recommended as an official method for determination of amoxicillin in these drugs products. However, the developed method is much simpler and cheaper. Moreover, it is characterized by high reproducibility and rapidity. The $S_{\mathrm{r}}$ value does not exceed the common values of spectrophotometry errors.

\section{6. Validation Characteristics of the AM Determination in Tablets "Amoxil" Using SA and STZ}

Additionaly, the validation of the developed methods for amoxicillin determination in tablet "Amoxil", which contains excipients such as povidone, sodium starch glycolate Type A, and calcium stearate, has been carried out. The following characteristics - the linearity, the accu- racy, and the precision in the range of 75\%-125\% (with SA determination) and 80\%-120\% (with STZ determination) from the nominal content of AM in the product, and the intermediate precision have been validated according to. ${ }^{19,41-43}$ The results are presented in Tables 7-9.

Calculated validation parameters of AM determination methods in "Amoxil" tablets using sulphanilamide and sulphathiazole satisfied the corresponding criteria, which allows us to suggest that the developed methods are suitable for the quality control of this drug in terms of "Assay". Although it should be noted that the method of AM determination using SA in tablets "Amoxil" has the better reproducibility, since the calculated value of $\Delta_{\text {intra }}$ is less than in the case of using STZ.

\section{Conclusions}

For the first time the formation of azo compounds by the interaction of diazotized sulphanilamide and sulphathiazole with amoxicillin has been established. Optimum conditions for examined sulphanilamides diazotization as well as the following azo-coupling with AM have been investigated. The components ratio in the obtained azo compounds is AM:SA(STZ)=1:1. The azo-coupling occurs due to the phe-

Table 7. The criteria of the linearity, the accuracy, and the precision of AM determination using SA in the preparation of "Amoxil" tablets.

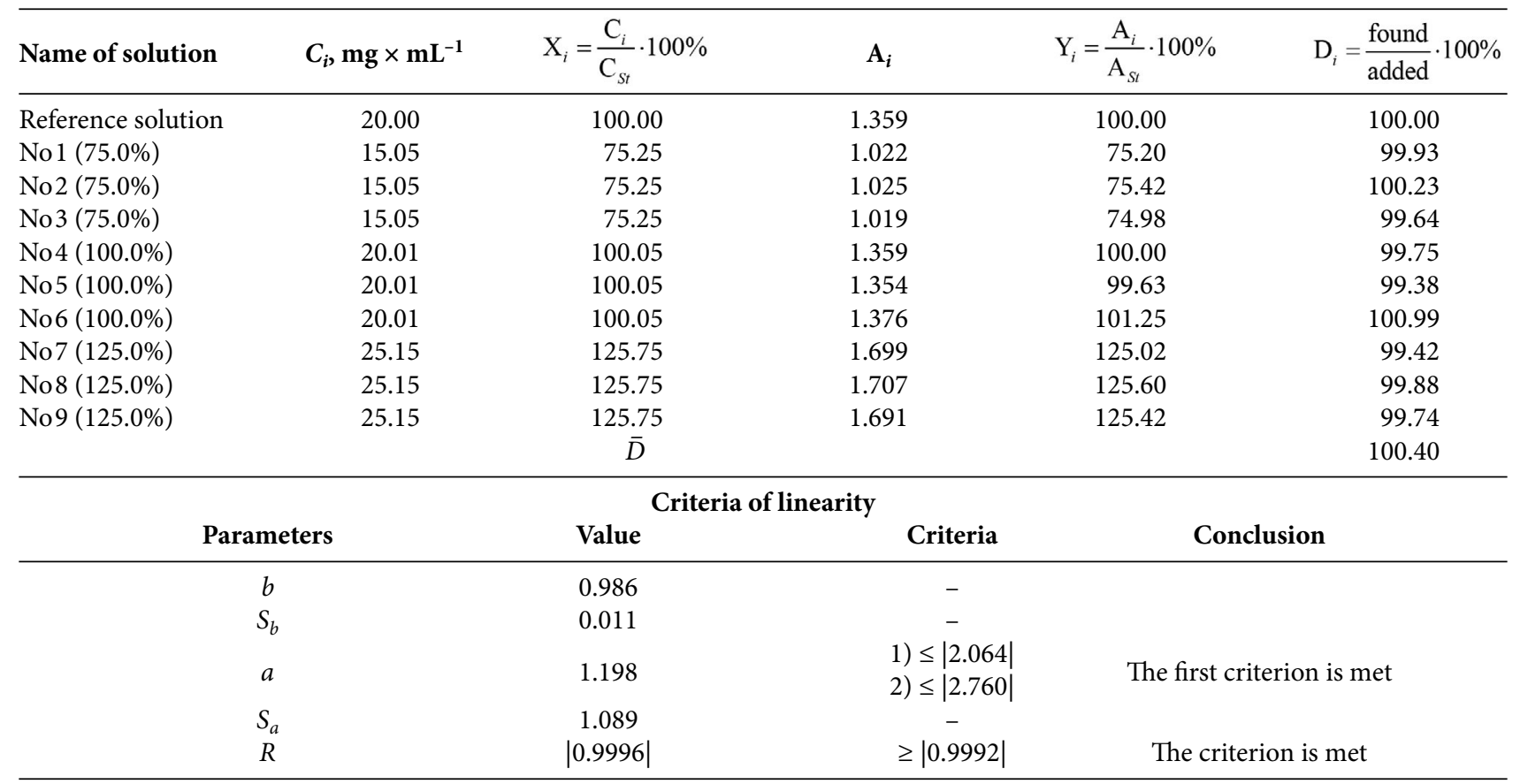

The criteria of the accuracy and the precision

The relative standard deviation $R S D_{0}=0.489 \%$

Critical values of the one-sided confidence interval, $\Delta x=0.910 \%$

Criterion of the systematic error insignificance, $\delta=0.12 \%$

The overall conclusion on methods
$\Delta x \leq 1.6 \%$

1. $\delta \leq 0.303 \%$

2. $\delta \leq 0.512 \%$
Satisfies the requirements

Satisfies the requirements (the first criterion)

Is correct 
Table 8. The criteria of the linearity, the accuracy, and the precision of AM determination using STZ in the preparation of "Amoxil" tablets.

\begin{tabular}{|c|c|c|c|c|c|}
\hline Name of solution & $C_{i}, \mathbf{m g} \times \mathbf{m L}^{-1}$ & $\mathrm{X}_{i}=\frac{\mathrm{C}_{i}}{\mathrm{C}_{S t}} \cdot 100 \%$ & $\mathbf{A}_{i}$ & $\mathrm{Y}_{i}=\frac{\mathrm{A}_{i}}{\mathrm{~A}_{S t}} \cdot 100 \%$ & $\mathrm{D}_{i}=\frac{\text { found }}{\text { added }} \cdot 100 \%$ \\
\hline Reference solution & 15.00 & 100.00 & 1.246 & 100.00 & 100.00 \\
\hline No1 $(80.0 \%)$ & 12.05 & 80.33 & 1.021 & 81.94 & 81.94 \\
\hline No2 (80.0\%) & 12.05 & 80.33 & 1.015 & 81.46 & 81.46 \\
\hline No3 (80.0\%) & 12.05 & 80.33 & 1.019 & 81.78 & 81.78 \\
\hline No4 (90.0\%) & 13.52 & 90.13 & 1.119 & 89.81 & 89.81 \\
\hline No5 (90.0\%) & 13.52 & 90.13 & 1.122 & 90.05 & 90.05 \\
\hline No6 (90.0\%) & 13.52 & 90.13 & 1.125 & 90.29 & 90.29 \\
\hline No7 (100.0\%) & 14.98 & 99.87 & 1.246 & 100.00 & 100.00 \\
\hline No8 (100.0\%) & 14.98 & 99.87 & 1.240 & 99.52 & 99.52 \\
\hline No9 (100.0\%) & 14.98 & 99.87 & 1.242 & 99.68 & 99.68 \\
\hline No $10(110.0 \%)$ & 16.44 & 109.60 & 1.353 & 108.59 & 108.59 \\
\hline No $11(110.0 \%)$ & 16.44 & 109.60 & 1.381 & 110.83 & 110.83 \\
\hline No $12(110.0 \%)$ & 16.44 & 109.60 & 1.362 & 109.31 & 109.31 \\
\hline No $13(120.0 \%)$ & 17.90 & 119.36 & 1.471 & 118.06 & 118.06 \\
\hline No $14(120.0 \%)$ & 17.90 & 119.36 & 1.482 & 118.94 & 118.94 \\
\hline No $15(120.0 \%)$ & 17.90 & $\begin{array}{c}119.36 \\
\bar{D}\end{array}$ & 1.475 & 118.38 & $\begin{array}{l}118.38 \\
100.18\end{array}$ \\
\hline \multicolumn{6}{|c|}{ Criteria of linearity } \\
\hline \multicolumn{2}{|c|}{ Parameters } & Value & Criteria & \multicolumn{2}{|c|}{ Conclusion } \\
\hline \multicolumn{2}{|c|}{$b$} & 0.952 & - & \\
\hline \multicolumn{2}{|c|}{$S_{b}$} & 0.009 & - & \multirow{2}{*}{\multicolumn{2}{|c|}{ The second criterion is met }} \\
\hline \multicolumn{2}{|c|}{$a$} & 4.837 & $\begin{array}{l}1) \leq|2.395| \\
\text { 2) } \leq|6.072|\end{array}$ & & \\
\hline \multicolumn{2}{|c|}{$S_{a}$} & 0.990 & - & \multirow{2}{*}{\multicolumn{2}{|c|}{ The criterion is met }} \\
\hline \multicolumn{2}{|c|}{$R$} & |0.9993| & $\geq|0.9973|$ & & \\
\hline \multicolumn{6}{|c|}{ The criteria of the accuracy and the precision } \\
\hline \multicolumn{6}{|c|}{ The relative standard deviation $R S D_{0}=0.667 \%$} \\
\hline \multicolumn{3}{|c|}{ Critical values of the one-sided confidence interval, $\Delta x=1.181 \%$} & \multirow{3}{*}{$\begin{array}{c}\Delta x \leq 1.6 \% \\
1 . \delta \leq 0.394 \% \\
\text { 2. } \delta \leq 0.512 \%\end{array}$} & \multirow{2}{*}{\multicolumn{2}{|c|}{$\begin{array}{l}\text { Satisfies the requirements } \\
\text { Satisfies the requirements } \\
\text { (the first criterion) }\end{array}$}} \\
\hline \multicolumn{3}{|c|}{ Criterion of the systematic error insignificance, $\delta=0.18 \%$} & & & \\
\hline The overall conclusi & methods & & & \multicolumn{2}{|c|}{ Is correct } \\
\hline
\end{tabular}

Table 9. Test results of the intermediate precision of AM quantitative determination in "Amoxil" tablets

\begin{tabular}{|c|c|c|c|c|}
\hline \multirow[t]{2}{*}{ Analysis No } & \multicolumn{2}{|c|}{$\begin{array}{c}\mathrm{SA}+\mathrm{AM} \\
m_{i}, m g / \text { tablets }\end{array}$} & \multicolumn{2}{|c|}{$\begin{array}{c}\mathrm{STZ}+\mathrm{AM} \\
m_{i}, \text { mg/tablets }\end{array}$} \\
\hline & $\begin{array}{c}1^{\text {st }} \text { day } \\
\text { (experiment } 1)\end{array}$ & $\begin{array}{c}2^{\text {nd }} \text { day } \\
\text { (experiment 2) }\end{array}$ & $\begin{array}{c}2^{\text {nd }} \text { day } \\
\text { (experiment } 2)\end{array}$ & $\begin{array}{c}1^{\text {st }} \text { day } \\
(\text { experiment } 1)\end{array}$ \\
\hline 1 & 250.7 & 250.7 & 243.7 & 245.1 \\
\hline 2 & 249.4 & 245.7 & 247.8 & 247.2 \\
\hline 3 & 249.3 & 245.1 & 245.8 & 252.8 \\
\hline 4 & 252.2 & 248.6 & 244.8 & 246.3 \\
\hline 5 & 250.6 & 249.2 & 250.4 & 253.3 \\
\hline average $(\bar{m})$ & 250.4 & 247.9 & 246.5 & 248.9 \\
\hline combined average $\left(\bar{m}_{\text {intra }}\right)$ & \multicolumn{2}{|c|}{249.2} & \multicolumn{2}{|c|}{247.7} \\
\hline $\mathrm{S}_{m}$ & 1.16 & 2.31 & 2.67 & 3.82 \\
\hline $\mathrm{S}_{\text {intra }} 44,45$ & \multicolumn{2}{|c|}{1.64} & \multicolumn{2}{|c|}{2.31} \\
\hline$\Delta_{\text {intra }} 44,45$ & \multicolumn{2}{|c|}{1.34} & \multicolumn{2}{|c|}{1.54} \\
\hline
\end{tabular}

nol group of second component (AM), which has concordantly oriented substituents. The effective molar absorptivi- ties of obtained azo compounds of amoxicillin with SA and STZ $\mathrm{e}_{445}\left(\mathrm{e}_{448)}\right.$ are $\sim 10^{4} \mathrm{~L} \times \mathrm{mol}^{-1} \times \mathrm{cm}^{-1}$. Methods allow to 
determine the wide range of AM concentrations (0.7$\left.32.9 \mu \mathrm{g} \times \mathrm{ml}^{-1}\right)$. Limit of detection for AM determination using SA is $0.40 \mathrm{mg} \times \mathrm{ml}^{-1}$ and using STZ is $0.23 \mu \mathrm{g} \times \mathrm{ml}^{-1}$.

The elaborated methods of AM spectrophotometric determination with SA and STZ have been approved during the analysis of single-component and combined commercial pharmaceuticals. Obtained data correlated rather well with the content of the AM specified by the manufacturer. The validation parameters of AM determination in tablets "Amoxil" using SA and STZ clearly indicate the reproducibility $\left(S_{\mathrm{r}} \leq 0.015(\mathrm{SA})\right.$ or $\left.0.018(\mathrm{STZ})\right)$, the specificity, the robustness, the precision, and the accuracy of both tested methods corresponding to modern requirements of specification.

The proposed method is simple, rapid, sensitive, selective, cost efficient, and competes with most of the spectrophotometric methods available in literature. Therefore, the recommended procedure is well-suited for the assay of drugs to assure high standard of quality control.

\section{References}

1. British Pharmacopoeia (BPh), British Pharmacopoeia Commission, TSO (The Stationery Office), 2019

2. Bird A. E. Amoxicillin: Analytical Profiles of Drug Substances and Excipients, G. Brittain - Surrey: Academic Press, 1994, 23, P.1-52. DOI:10.1016/S0099-5428(08)60599-7

3. Belikov V. G. Pharmaceutical Chemistry: Textbook. 2nd Edition, MED Press Inform, Moscow, Russia, 2007, p. 624.

4. A.P. Arzamastsev Pharmaceutical and Toxicological Chemistry, GEOTAR-MED, Moscow, Russia, 2004, p. 640.

5. M. N. Uddin, S. Das, S. H. Khan, J. Taibah Univ. Sci., 2016, 10, p. 755-765. DOI:10.1016/j.jtusci.2015.11.005

6. S.M. Sabry, M.H. Abdel-Hay, T.S. Belal, A. A. Mahgoub, Ann Pharm Fr., 2015, 73, p. 351-360.

DOI:10.1016/j.pharma.2015.04.008

7. H. Li, X. Xia, Y. Xue, S Tang, X Xiao, J Li, J Shen, J. Chromatogr. B. 2012, 900, p. 59-63. DOI:10.1016/j.jchromb.2012.05.031

8. Ch. Liua, H. Wangb, Y. Jiangb, Z. Du, J. Chromatogr. B., 2011, 879, p. 533-540. DOI:10.1016/j.jchromb.2011.01.016

9. S. M. Foroutan, A. Zarghib, Al. Shafaatib A. Khoddam, H. Movahed, J. Pharm. Biomed. Anal., 2007, 45, p. 531-534. DOI:10.1016/j.jpba.2007.06.019

10. M. Dhoka, V. Gawande, Pr. Joshi, J. Pharm. Pharm. Sci., 2010, 2, p. 129-133.

11. R. V. Rele, and Pr. P. Tiwatane, Res. J. Recent Sci., 2018, 7, p. $8-13$.

12. B. Wang M. Pang, X. Xie M. Zhao, Food Anal. Methods, 2017, 10 p. 1-14. DOI:10.1007/s12161-017-0900-8

13. H. Karimi-Maleh, F. Tahernejad-Javazmi, V. K. Gupta H. Ahmar, J. Mol. Liq,. 2014, 196, p. 258-263.

DOI:10.1016/j.molliq.2014.03.049

14. A. Pollap, P. Knihnicki, P. Kustrowski, J. Kozak, M. Golda-Cepa, A. Kotarba, J. Kochana, Electroanalysis, 2018, 30, p. 23862396. DOI:10.1002/elan.201800203
15. R. Ojani, J.-B. Raoof, S. Zamani, Bioelectrochem., 2012, 85, p. 44-49. DOI:10.1016/j.bioelechem.2011.11.010

16. G. Yanga, F. Zhao, Electrochim. Acta., 2015, 174, p. 33-40. DOI:10.1016/j.electacta.2015.05.156

17. B. Norouzi, T. Mirkazemi, Russ. J. Electrochem., 2016. 52, p. 37-45. DOI:10.1134/S1023193516010067

18. Gh. Absalan, M. Akhond, H. Ershadifar, J. Solid State Electrochem., 2015, 19, p. 2491-2499.

DOI:10.1007/s10008-015-2894-8

19. United States Pharmacopoeia, USP 41-NF 36 (Convention Inc., Rockville, MD XXVI, 2017)

20. S. M. Sinaga, F. Arinawati, M. Bachri, Int. J. Pharmtech. Res., 2016, 9, p. 79-89.

21. R.V. Rele, Res. J. Pharm. Sci., 2017, 6, P. 1-5.

22. R. V. Rele, Der Pharmacia Lett., 2016, 8, p. 191-196.

23. W. A. Al-Uzri, Iraqi J. Sci., 2012, 53, p. 713-722.

24. H. Salem, Anal. Chim. Acta., 2004, 515, p. 333-341. DOI:10.1016/j.aca.2004.03.056

25. Z. A-A. Khammas, H. M. Abdulkareem, Sci. J. Anal. Chem., 2016, 4, p. 66-76. DOI:10.11648/j.sjac.20160405.12

26. S. M. El-Ashry, F. Belal, M. M. El-Kerdawy, D. R. El Wasseef, Mikrochim. Acta. 2000, 135, p. 191-196.

DOI:10.1007/s006040070010

27. H. A. Qader, N. A. Fakhri, Ibn Al-Haitham Jour. for Pure \& Appl. Sci., 2015, 28, p. 142-153.

28. G. G. Mohamed, J Pharm. Biomed. Anal., 2001, 24, P, 561567. DOI:10.1016/S0731-7085(00)00463-5

29. P. B. Issopoulos, J Pharm. Biomed. Anal., 1988, 6, p. 321-327. DOI:10.1016/0731-7085(88)80060-8

30. M. Smolinska, O. Korkuna, I. Kotsyumbas, T. Vrublevska, G. Teslyar, Methods and objects of chemical analysis, 2016, 11, p. 51-81.

31. M. Boiko, T. Vrublevska, O. Korkuna, G. Teslyar, Spectrochim. Acta A, 2011, 79A, 325-331.

DOI:10.1016/j.saa.2011.02.036

32. M. Boiko, T. Vrublevska, O. Korkuna, I. Kotsyumbas, G. Teslyar. Voprosy Khimii i Khimicheskoi Tekhnologii, 2012, 2, 116-126.

33. M. Smolinska, O. Korkuna, P. Rydchuk, T. Vrublevska, G. Teslyar. Open Chem., 2015, 13, 1254-1268.

DOI:10.1515/chem-2015-0139

34. H. Zollinger, Chemistry of Azo Dyes, Goskhimizdat, Leningrad, 1960. (in Russian).

35. A. F. Minka, A. F. Shkadova, I. I. Kopiychuk, Farm. Zhurn., 1987, 1, 38.

36. A. Calvin Bratton, E.K. Marshall, J. Biol. Chem., 1939, 128, p. 537-550.

37. P. Nagaraja, H. S. Yathirajan, C. R. Raju, R. A.Vasantha, P. Nagendra, M. S. Hemantha Kumar, Il Farmaco, 2003, 58, p. 1295-1300.

DOI:10.1016/S0014-827X(03)00093-4

38. G. Vijaya Raja, C. Bala Sekaran, P. Siva Kumari, S. K. Parveen, P.V.S. Mahesh, Oriental J. Chem., 2008, 24, p. 1021-1024.

39. P. Nagaraja, K. R. Sunitha, R. A. Vasantha, H. S. Yathirajan, Eur. J. Pharm. Biopharm., 2002, 53, p. 187-192.

DOI:10.1016/S0939-6411(01)00235-1 
40. S. M. Sabry, Anal. Lett. 2006, 39, p. 2591-2615.

DOI:10.1080/00032710600824748

41. European Pharmacopoeia (Eur. Ph.). 9-th Ed. (Strasbourg: Council of Europe, 2017)

42. State Pharmacopoeia of Ukraine Add.2 (State Enterprise "Scientific-Expert Pharmacopoeial Centre." Kharkiv: Rieger, 2008) (in Ukrainian)
43. Note for guidance on validation of analytical procedures: text and methodology (CPMP/ICH/381/95)

44. A. I. Gryzodub, Farmacom, 2002, 3, p. 42. (in Russian)

45. A. I. Gryzodub, N. Zvolynskaya, N. Arkhipova, D.A. Leont'ev et al. Farmacom, 2004, 2, 20. (in Russian)

\section{Povzetek}

Opisana je hitra, preprosta in občutljiva spektrofotometrijska metoda za določanje amoksicilina (AM). Metoda je osnovana na začetni diazotizaciji sulfanilamida (SA) in sulfatiazola (STZ) v mediju 0,6-0,7 M klorovodikove kisline ter njuni nadaljnji interakciji $\mathrm{z}$ amoksicilinom pri pH 10,5, pri čemer nastaneta rumeno obarvani azo spojini. Efektivna molarna absorptivnost za azo spojine pri absorpcijskem maksimumu $445 \mathrm{~nm}(\mathrm{SA})$ je bila $(1,74 \pm 0,06) \cdot 10^{4} \mathrm{~L} \times \mathrm{mol}^{-1} \times \mathrm{cm}^{-1}$ in pri $448 \mathrm{~nm}(\mathrm{STZ})(1,97 \pm 0,05) \cdot 10^{4} \mathrm{~L} \times \mathrm{mol}^{-1} \times \mathrm{cm}^{-1}$. Stehiometrijsko razmerje med obema komponentama azo spojin smo določili $\mathrm{z}$ metodo kontinuirne variacije. Pri optimalnih reakcijskih pogojih smo razvili dve novi metodi. Ti dve metodi omogočata določitev amoksicilina $\mathrm{v}$ koncentracijskem območju $1,3-32,9 \mu \mathrm{g} \times \mathrm{mL}^{-1} \mathrm{~s}$ sulfanilamidom in $0,7-27,4 \mu \mathrm{g} \times \mu \mathrm{L}^{-1}$ s sulfatiazolom. Metodi smo uspešno validirali za določevanje amoksicilina v tabletah »Amoxil«. 